\title{
KEBIASAAN CUCI TANGAN, BERJEMUR, DAN MEDIA INFORMASI PADA MASYARAKAT SUMATRA SELATAN SELAMA MASA PANDEMI COVID-19
}

\author{
Elya $^{1)}$, Windi Indah Fajar Ningsih' ${ }^{1)}$, Eliza $^{2)}$, Andi Eka Yunianto ${ }^{3)}$, Emy Yuliantini ${ }^{4}$, \\ Miratul Haya ${ }^{5}$, Ahmad Faridi ${ }^{6}$ \\ ${ }^{1}$ Jurusan Gizi, Dinas Kesehatan Provinsi Sumatera Selatan \\ ${ }^{2}$ Jurusan Gizi, Universitas Sriwijaya \\ ${ }^{3}$ Jurusan Gizi, Poltekkes Kemenkes Palembang \\ ${ }^{4}$ Jurusan Gizi, Universitas Siliwangi \\ 5,Jurusan Gizi, Poltekkes Kemenkes Bengkulu \\ ${ }^{6}$ Jurusan Gizi, Universitas Muhammadiyah Prof. Dr. Hamka \\ E-mail: andi.eka@unsil.ac.id
}

\begin{abstract}
Problems:COVID-19 is an infectious disease caused by corona virus. This study aims to look at the habit of washing hands, sunbathing, and media information obtained by the people of southern Sumatra during the COVID19 pandemic. The Aim Of The Research: To see the habits of washing hands, sunbathing and media information about COVID-19 in the people of South Sumatra Province during the pandemic. Research Method: This study used a cross-sectional design with 419 respondents as many as 16 years old who lived in South Sumatra Province. The questionnaire in this study was in the form of e-survey using google form media and distributed through social media (Whatsapp, Facebook, and Instagram). A Chi-square test was used to see the relationship between hand washing, sunbathing, and media information on men and women. The Results:showed that hand washing $(\mathrm{OR}=$ 1,127; 95\% CI: 1,089 - 1,167) there was no significant relationship between men and women, while there was a significant relationship in sunbathing $(\mathrm{OR}=1,884 ; 95 \% \mathrm{CI}$ : $0.992-3,581)$ and information media $(\mathrm{OR}=0.473$; 95\% CI: 0.246 - 0.911). Conclusions:The community is expected to apply the habit of washing hands, sunbathing, and digging information in various media in overcoming the prevention and impact of COVID-19.
\end{abstract}

Keywords:Washing Hands, Sunbathing, Information Media, COVID-19

\begin{abstract}
ABSTRAK
Permasalahan:COVID-19 merupakan penyakit yang mudah menular yang diakibatkan oleh virus korona. Penelitian ini bertujuan untuk melihat kebiasaan cuci tangan, berjemur dan media informasi yang diperoleh masyarakat sumatera selatan selama masa pandemik COVID-19.Tujuan Penelitian:untuk melihat kebiasaan cuci tangan, berjemur dan media informasi mengenai COVID-19 pada masyarakat Provinsi Sumatera Selatan dalam masa pandemi.Metode Penelitian:Penelitian ini menggunakan desain cross-sectional dengan jumlah responden sebayak 419 dengan kriteria umur diatas 16 tahun yang tinggal di Provinsi Sumatera Selatan. Kuesioner dalam penelitian ini berbentuk e-survey dengan menggunakan media google form dan disebarkan melalui media sosial (Whatsapp, Facebook, dan Instragram). Chi-square test digunakan untuk melihat hubungan kebiasaan cuci tangan, berjemur dan media informasi terhadap pria dan wanita.Hasil: menunjukkan bahwa cuci tangan $(\mathrm{OR}=1,127 ; 95 \%$ CI: 1,089 - 1,167) tidak terdapat hubungan yang signifikan para pria dan wanita, sedangkan terdapat hubungan yang signifikan berjemur $(\mathrm{OR}=1,884 ; 95 \% \mathrm{CI}: 0,992-3,581)$ dan media informasi $(\mathrm{OR}=0,473 ; 95 \% \mathrm{CI}$ : $0,246-$ 0,911). Kesimpulan:Masyarakat diharapkan dapat menerapkan kebiasaan cuci tangan, berjemur dan menggali informasi pada berbagai media dalam mengatasi pencegahan dan dampak dari COVID-19.
\end{abstract}

Kata Kunci:Cuci Tangan, Berjemur, Media Informasi, COVID-19 


\section{PENDAHULUAN}

Coronavirus 2019 (COVID-19) adalah penyakit yang menyebabkan pneumonia terdeteksi pertama kali pada bulan desember 2019 di Wuhan, Cina(Lu, Stratton and Tang, 2020). Pada tahap awal pneumonia ini terjadi gejala infeksi pernapasan akut yang parah, dengan beberapa pasien mengalami sindrom gangguan pernapasan akut, gagal pernapasan akut, dan komplikasi serius lainnya. Gejala klinis utamanya yaitu demam, batuk kering, kelelahan, dan myalgia(Chen et al., 2020; Guan et al., 2020). Prevalensi COVID-19 di dunia khususnya di Indonesia dari bulan maret sampai july mengalami penambahan yang signifikan(World Health Organization, 2020).

WHO menyatakan bahwa dalam mencegah penyebaran virus COVID-19 kebersihan tangan sangat penting dilakukan pada kehidupan sehari-hari. Hal ini dapat mencegah transmisi virus dan bakteri lain yang menyebabkan demam, flu dan pneumonia, sehingga mengurangi beban penyakit secara umum. Meskipun kesadaran akan pentingnya kebersihan tangan dalam mencegah infeksi dengan virus COVID-19 tinggi, akses ke fasilitas kebersihan tangan yang mencakup gosok tangan berbasis alkohol serta sabun dan air(Mk et al., 2020).

Sinar matahari pagi, terutama sebelum pukul 10.00 pagi, memang memiliki banyak manfaat untuk kesehatan. Ketika terserap oleh kulit, sinar ultraviolet pada cahaya matahari akan merangsang tubuh untuk menghasilkan vitamin D (Wacker and Holick, 2013). Vitamin D yang diproduksi oleh tubuh dari proses berjemur di bawah sinar matahari memiliki banyak manfaat bagi kesehatan (Lucas et al., 2018). Vitamin D dapat meningkatkan kadar kalsium dan fosfor di dalam tubuh, menjaga fungsi otot dan saraf, serta meningkatkan daya tahan atau sistem imun tubuh dalam melawan infeksi (González Maglio, Paz and Leoni, 2016; Alodokter, 2020).

Di tengah wabah COVID-19 yang melanda hampir seluruh negara, termasuk Indonesia, beragam cara dilakukan masyarakat untuk mencegah semakin meluasnya penyebaran virus Corona. Salah satu cara yang dianggap paling mudah dan praktis adalah dengan berjemur. Meski sinar matahari tidak dapat membunuh virus Corona, aktivitas berjemur memiliki manfaat yang tidak sedikit bagi kesehatan. Selain meningkatkan kekuatan tulang dan otot serta daya tahan tubuh, berjemur juga bermanfaat untuk menjaga kesehatan mental dan membuat tidur lebih lelap (Alodokter, 2020). Penelitian ilmuwan dari Universitas Aix-Marseille, Prancis menyatakan corona virus bisa bertahan di suhu 60 derajat Celsius, selama sejam. Namun, virus bisa tidak aktif sama sekali dalam waktu 15 menit setelah dipapar suhu 92 derajat(Pastorino et al., 2020). 
Pemerintah memiliki beberapa langkah dalam mengatasi wabah COVID-19 yaitu dengan cara memberikan beberapa informasi melalui berbagai media. Media informasi ini dapat diperoleh berupa media cetak, radio, televise dan bahkan dapat diakses melalui media internet khususnya media sosial. Media sosial merupakan media yang paling sering diakses oleh masyarakat dalam hal informasi terutama berita-berita terkini tentang perkembangan COVID-19(Untari, 2020). Penggunaan media sosial secara sering berkontribusi pada informasi yang dapat memberikan pengetahuan yang lebih banyak pada masyarakat mengenai COVID-19(Farooq, Laato and Islam, 2020). Berdasarkan hal tersebut, peneliti ingin melihat kebiasan cuci tangan, berjemur dan media informasi mengenai COVID-19 pada masyarakat Provinsi Sumatera Selatan dalam masa pandemi.

\section{METODE PENELITIAN}

Penelitian ini menggunakan desain cross-sectional study dilakukan pada bulan Juni 2020. Responden dalam penelitian ini sebanyak 419 orang dengan kriteria inklusi yaitu usia diatas 16 tahun yang bertempat tinggal di seluruh provinsi Sumatera Selatan. Penelitian ini sudah disetujui oleh Komite Etik Penelitian Kesehatan (KEPK) Poltekkes Kemenkes Bengkulu No. KEPK/063/06/2020.Penelitian ini merupakan bagian dari penelitian yang berjudul Pengetahuan, Sikap, dan Praktik serta Gaya Hidup Masyarakat Indonesia dalam Mengadapi COVID-19 di Indonesia.Kuesioner disebarkan dengan aplikasi google form melalui media social seperti whattsapp, facebook dan instagram.Data dianalisis secara deskriptid dan inferensia dengan menggunakan Microsoft Excel 2013 dan SPSS versi 25 for Windows. Chi-square test digunakan untuk menganalisis hubungan kebiasaan cuci tangan, berjemur dan media informasi pada pria dan wanita dengan taraf $\mathrm{p}<0,05$.

\section{HASIL}

Tabel 1 Karakteristik Responden

\begin{tabular}{|c|c|c|c|c|c|c|}
\hline \multirow{2}{*}{$\begin{array}{l}\text { Karakteristik } \\
\text { Responden }\end{array}$} & \multicolumn{2}{|c|}{ Pria } & \multicolumn{2}{|c|}{ Wanita } & \multicolumn{2}{|c|}{ Total } \\
\hline & $\mathbf{n}$ & $\%$ & $\mathbf{n}$ & $\%$ & n & $\%$ \\
\hline \multicolumn{7}{|l|}{ Umur } \\
\hline$<19$ tahun & 9 & 4,8 & 177 & 95,2 & 186 & 100 \\
\hline$>=19$ tahun & 38 & 16,3 & 195 & 83,7 & 233 & 100 \\
\hline \multicolumn{7}{|c|}{ Status pernikahan } \\
\hline Belum menikah & 32 & 8,8 & 331 & 91,2 & 363 & 100 \\
\hline menikah & 15 & 26,8 & 41 & 73,2 & 56 & 100 \\
\hline \multicolumn{7}{|l|}{ Pendidikan } \\
\hline$<$ SMA & 23 & 7.1 & 302 & 92,9 & 325 & 100 \\
\hline
\end{tabular}




\begin{tabular}{lcccccc}
\hline Perguruan tinggi & 24 & 25,5 & 70 & 74,5 & 94 & 100 \\
Pekerjaan & & & & & & \\
Tidak bekerja & 16 & 8.7 & 167 & 91,3 & 183 & 100 \\
Bekerja & 31 & 13,1 & 205 & 86,9 & 236 & 100 \\
\hline
\end{tabular}

Tabel 1 menunjukkan bahwa sebagian besar responden wanita usia kurang dari 19 tahun sebanyak 95,2\% dan usia lebih dari 19 tahun sebanyak 83,7\%. Berdasarkan status pernikahan sebagian besar wanita $91,2 \%$ belum menikah dan $8,8 \%$ pria belum menikah, sedangkan $73,2 \%$ wanita dan $26,8 \%$ pria dengan status menikah. Pendidikan wanita sebagian besar lulusan SMA sederajat sebanyak 92.9\% dan 74,5\% merupakan lulusan perguruan tinggi serta sebagian kecil pria $25,5 \%$ lulusan perguruan tinggi dan 7,1\% lulusan SMA sederajat. Sebagian besar wanita $86,9 \%$ dan pria $13,1 \%$ yang bekerja serta sebanyak $91,3 \%$ wanita dan $8,7 \%$ pria yang tidak bekerja.

Tabel 2 Kebiasaan Cuci Tangan, Berjemur, dan Media Informasi mengenai COVID-19 pada Masyarakat Provinsi Sumatera Selatan

\begin{tabular}{|c|c|c|c|c|c|c|c|c|}
\hline \multirow{2}{*}{$\begin{array}{l}\text { Kebiasaan } \\
\text { Masyarakat }\end{array}$} & \multicolumn{2}{|c|}{ Pria } & \multicolumn{2}{|c|}{ Wanita } & \multicolumn{2}{|l|}{ Total } & \multirow[t]{2}{*}{ p } & \multirow[t]{2}{*}{ OR } \\
\hline & $\mathbf{n}$ & $\%$ & $\mathrm{n}$ & $\%$ & $\mathbf{n}$ & $\%$ & & \\
\hline \multicolumn{9}{|l|}{ Cuci tangan } \\
\hline Jarang & 0 & 0 & 3 & 100 & 3 & 100 & \multirow[t]{3}{*}{0,537} & 1,127 \\
\hline Sering & 47 & 11,3 & 369 & 88,7 & 416 & 100 & & $(1,089-1,167)$ \\
\hline \multicolumn{8}{|l|}{ Berjemur } & \\
\hline $\begin{array}{l}\text { Jarang (<3 } \\
\text { kali/minggu) }\end{array}$ & 17 & 16,5 & 86 & 83,5 & 103 & 100 & \multirow[t]{3}{*}{$0,050 *$} & \multirow{3}{*}{$\begin{array}{c}1.884 \\
(0,992-3,581)\end{array}$} \\
\hline $\begin{array}{l}\text { Sering }(\geq 3 \\
\text { kali/mimggu) }\end{array}$ & 30 & 9,5 & 286 & 90,5 & 316 & 100 & & \\
\hline \multicolumn{7}{|c|}{$\begin{array}{l}\text { Media tentang } \\
\text { covid }\end{array}$} & & \\
\hline Media Sosial & 31 & 9,4 & 299 & 90,6 & 330 & 100 & $0,023 *$ & 0.473 \\
\hline Lainnya & 16 & 18,0 & 73 & 82,0 & 89 & 100 & & $(0,246-0,911)$ \\
\hline
\end{tabular}

Berdasarkan Tabel 2 menunjukkan bahwa tidak terdapat hubungan yang signifikan antara pria dan wanita.Wanita yang mencuci tangan lebih sering 1,127 kali dibandingan dengan pria.Kebiasaan berjemur memiliki hubungan yang signifikan antara pria dan wanita.Wanita lebih sering berjemur 1,884 kali dibandingan pria.Menurut media informasi tentang COVID-19 menunjukkan bahwa terdapat hubungan signifikan antara pria dan wanita.Wanita lebih tinggi 0,473 kali terpapar media sosial dibandingkan pria dalam mengakses informasi tentang COVID-19.

\section{PEMBAHASAN}

Perilaku cuci tangan merupakan salah satu upaya dalam mencegah penyebaran virus COVID-19.Cuci tangan yang baik yaitu dengan menggunakan sabun dan air yang mengalir. Cuci tangan sebaiknya dilakukan denga durasi waktu 20 sampai 30 detik(UNICEF, 2020). 
Mencuci tangan juga dapat mencegah beberapa penyakit seperti diare dan hepatitis A (Rifai, Wahab and Prabandari, 2016; Dimyanti, 2017; Srisantyorini et al., 2020). Berdasarkan uji bivariat menunjukkan bahwa tidak terdapat hubungan yang signifikan kebiasaan antara pria dan wanita di Provinsi Sumatera Selatan. Hal ini berbeda dengan penelitian sebelumnya yanga dilakukan oleh (Lestari, 2019) yang menunjukkan bahwa terdapat hubungan yang signifikan perilaku masyarakat terhadap kebiasaan cuci tangan. Kebiasaan cuci tangan erat hubungannya dengan tingkat pengetahuan dan sikap yang dimiliki oleh setiap individu di masyarakat (Fatih, 2017). Semakin tinggi pengetahuan dan sikap seseorang maka semakin sadar masyarakat akan pentingnya cuci tangan dalam menjaga kesehatan dalam kehidupan sehari-hari(Lestari, 2019).

Kebiasaan berjemur merupakan salah satu dari bentuk pencegahan terhadap COVID19. Kebiasaan berjemur pada secara sering pada masyarakat memiliki hubungan yang signifikan $(\mathrm{p}=0.05)$ antara pria dan wanita di Sumatera Selatan. Wanita memiliki kebiasaan sering berjemur 1,884 kali dibandingkan dengan pria. Kebiasaan berjemur dapat membantu dalam penyerapan vitamin $\mathrm{D}$ dan membatu dalam penyerapan kalsium di dalam tubuh (Lucas et al., 2018). Vitamin D juga di butuhkan dalam menjaga imunitas tubuh. Imunitas dalam menangkal beberapa penyakit khususnya COVID-19(González Maglio, Paz and Leoni, 2016). Sinar matahari yang baik untuk berjemur yaitu ultraviolet B yang dapat kita peroleh diatas jam 9 sampai 12 dan di sore hari yaitu jam 3 sore. Berjemur sebaiknya dilakukan minimal 10 - 30 menit sehari agar mendapat mafaat vitamin D yang cukup (Nimitphong and Holick, 2013; Lucas et al., 2018).

Komunikasi yang terdapat pada media massa khususnya media sosial, merupakan salah satu strategi promosi kesehatan yang dirancang dalam merubah perilaku risiko kesehatan.Pada situasi pandemi media sosial tempat yang paling dicari dalam pengumpulan informasi dan penyebaran informasi pada era digital sekarang ini (R, D and waran, 2020). Media sosial secara cepat dapat mempengaruhi jutaan orang Indonesia secara bersamaan. Media sosial dapat memengaruhi perilaku individu untuk mempertahankan kebiasaan hidup sehat (Alber et al., 2016). Media sosial memiliki hubungan yang signifikan $(\mathrm{p}=0,023)$ terhadap informasi mengenai COVID-19 pada masyarakat Sumatera Selatan. Wanita lebih tinggi 0,473 kali lebih sering mengakses media sosial dibandingkan dengan pria. hal ini sesuai dengan penelitian sebelumnya yang menyatakan bahwa budaya media sosial berdampak pada masyarakat selama pandemi COVID-19 (Sampurno, Kusumandyoko and Islam, 2020). Media sosial memberikan informasi mengenai perkembangan COVID-19 mulai dari jenis pathogen dan penyakit itu berasal, dimana wabah berada, gejala yang muncul, 
sumber pathogen, dan tindakan perlindungan diri masyarakat (Lu and Zhang, 2020). Selain itu, Media sosial juga dapat dapat mengedukasi masyarakat dan memberikan pengetahuan yang lebih mengenai upaya penanggulangan dan pencegahan wabah COVID-19 (Farooq, Laato and Islam, 2020).

\section{KESIMPULAN}

Kebiasaan Cuci tangan tidak menunjukkan hubungan yang signifikan antra pria dan wanita, sedangkan kebiasan berjemur dan media informasi COVID-19 memiliki hubungan yang signifikan pada pria dan wanita di Provinsi Sumatera Selatan.Kebiasan mencuci tangan, berjemur merupakan bagian upaya dalam mencegah dan mengatasi penanggulangan penyebaran pada masa pandemi COVID-19.Media informasi merupakan adalah salah satu bentuk informasi yang diperoleh oleh masyarakat sehingga diharapkan dapat memberikan pengetahuan yang lebih mengenai masalah pandemi yang dihadapi pada masa sekarang ini. Hal ini diharapkan masyarakat dapat meningkatkan gaya hidup sehat seperti kebiasaan mencuci tangan. Selain itu, kebiasaan berjemur salah satu upaya dalam meningkatkan daya tahan tubuh seseorang dalam melawan berbagai penyakit.

\section{DAFTAR PUSTAKA}

Alber, J. M. et al. (2016) 'Social Media Self-Efficacy of Health Education Specialists', Health Promotion Practice, 17(6), pp. 915-921. doi: 10.1177/1524839916652389.

Alodokter (2020) Mitos dan Fakta Seputar Berjemur saat Pandemi-Covid-19. Available at: https://www.alodokter.com/mitos-dan-fakta-seputar-berjemur-saat-pandemi-covid-19.

Chen, N. et al. (2020) 'Epidemiological and clinical characteristics of 99 cases of 2019 novel coronavirus pneumonia in Wuhan, China: a descriptive study', The Lancet. Elsevier Ltd, 395(10223), pp. 507-513. doi: 10.1016/S0140-6736(20)30211-7.

Dimyanti, kiki F. (2017) 'pengaruh Antara Aktivitas fisik, kebiasaan Merokok Dan Sikap Lansia Terhadap Kejadian Osteosporosis', Jurnal Berkala Epidemologi, 5(1), pp. 95106. doi: 10.20473/jbe.v5i1.

Farooq, A., Laato, S. and Islam, A. K. M. N. (2020) 'Impact of Online Information on SelfIsolation Intention During the COVID-19 Pandemic: Cross-Sectional Study', Journal of Medical Internet Research, 22(5), p. e19128. doi: 10.2196/19128.

Fatih, H. Al (2017) 'Hubungan Pengetahuan Dengan Perilaku Cuci Tangan Siswa Di Sekolah Dasar Negeri Kota Bandung', Jurnal Keperawatan BSI, 5(1), pp. 18-23.

González Maglio, D. H., Paz, M. L. and Leoni, J. (2016) 'Sunlight Effects on Immune System: Is There Something Else in addition to UV-Induced Immunosuppression?', BioMed Research International, 2016. doi: 10.1155/2016/1934518. 
Guan, W. et al. (2020) 'Clinical Characteristics of Coronavirus Disease 2019 in China', New England Journal of Medicine, 382(18), pp. 1708-1720. doi: 10.1056/NEJMoa2002032.

Lestari, A. O. A. W. (2019) 'Relationship Between Knowledge and Attitude To Hand', Jurnal Promkes: The Indonesian Journal of Health Promotion and Health Education, 7(1), pp. 1-11. doi: 10.20473/jpk.V7.I1.2019.1.

Lu, H., Stratton, C. W. and Tang, Y. (2020) 'Outbreak of pneumonia of unknown etiology in Wuhan, China: The mystery and the miracle', Journal of Medical Virology, 92(4), pp. 401-402. doi: 10.1002/jmv.25678.

Lu, Y. and Zhang, L. (2020) 'Social media WeChat infers the development trend of COVID19', Journal of Infection. Elsevier Ltd, 81(1), pp. e82-e83. doi: 10.1016/j.jinf.2020.03.050.

Lucas, R. M. et al. (2018) 'Are current guidelines for sun protection optimal for health? Exploring the evidence', Photochemical and Photobiological Sciences. Royal Society of Chemistry, 17(12), pp. 1956-1963. doi: 10.1039/c7pp00374a.

Mk, W. et al. (2020) 'Recommendation to Member States to improve hand hygiene practices widely to help prevent the transmission of the COVID-19 virus by: 1 . Providing universal access to public hand hygiene stations and making their use obligatory on entering and leaving any', pp. 2-4.

Nimitphong, H. and Holick, M. F. (2013) 'Prevalence of Vitamin D Deficiency in Asia Vitamin D status and sun exposure in Southeast Asia', Dermato-endocrinology, 5(1), pp. 34-37. doi: 10.4161/derm.24054.

Pastorino, B. et al. (2020) 'Evaluation of heating and chemical protocols for inactivating SARS-CoV-2', bioRxiv, (April), pp. 0-8. doi: 10.1101/2020.04.11.036855.

R, J., D, B. and waran, K. (2020) 'Social Media Reigned by Information or Misinformation About COVID-19: A Phenomenological Study', SSRN Electronic Journal, (May). doi: $10.2139 /$ ssrn.3596058.

Rifai, R., Wahab, A. and Prabandari, Y. S. (2016) 'Kebiasaan cuci tangan ibu dan kejadian diare anak: studi di Kutai Kartanegara', Berita Kedokteran Masyarakat, 32(11), pp. 409-414.

Sampurno, M. B. T., Kusumandyoko, T. C. and Islam, M. A. (2020) 'Budaya Media Sosial, Edukasi Masyarakat, dan Pandemi COVID-19', SALAM: Jurnal Sosial dan Budaya Syar-i, 7(5). doi: 10.15408/sjsbs.v7i5.15210.

Srisantyorini, T. et al. (2020) 'SEBAGAI UPAYA PENCEGAHAN HEPATITIS A DI PESANTREN SABILUNNAJAT INVESTIGATION CHARACTERISTICS OF HAND WASH HABITS AS A PREVENTION OF HEPATITIS A', (1).

UNICEF (2020) Fakta penting tentang cuci tangan pakai sabun untuk melindungi Anda dari 
coronavirus (COVID-19). Available at:

(https://www.unicef.org/indonesia/id/coronavirus/cuci-tangan).

Untari, P. H. (2020) Riset Ungkap Penggunaan Internet Meningkat saat Pandemi COVID-19. Available at: https://techno.okezone.com/read/2020/04/02/207/2192803/riset-ungkappenggunaan-internet-meningkat-saat-pandemi-covid- 19.

Wacker, M. and Holick, M. F. (2013) 'Sunlight and Vitamin D: A global perspective for health', Dermato-Endocrinology, 5(1), pp. 51-108. doi: 10.4161/derm.24494.

World Health Organization (2020) No Title, Coronavirus (COVID-19). Available at: https://covid19.who.int/. 